\title{
Cyclopenta[cd]fluoranthene and Its Precursors in Combustion Exhausts: A Survey of Their Bacterial Mutagenic Activity
}

\author{
María José Otero-Lobato, ${ }^{1}$ Leonardus W. Jenneskens, ${ }^{1 *}$ and Willem Seinen ${ }^{2}$ \\ 1 Debye Institute, Department of Physical Organic Chemistry, Utrecht University, \\ Utrecht, The Netherlands \\ 2 Institute for Risk Assessment Science, Department of Toxicology, Utrecht University, \\ Utrecht, The Netherlands
}

\begin{abstract}
Cyclopenta[cd]fluoranthene (1) and 3-ethynylfluoranthene (2) have both recently been identified in combustion exhausts. In this study, their mutagenic activities were compared to that of fluoranthene (3), one of the most abundant polycyclic aromatic hydrocarbons (PAHs) in combustion exhausts, in the Salmonella/microsome reversion assay (Ames assay) using $S$. typhimurium strain TA98. The mutagenicity of 1 was modest in comparison to other active cyclopenta PAHs. Unexpectedly, 2 was mutagenic both with and without exogenous metabolic activation (rat liver S9). Furthermore, cyclopenta[cd]fluoranthene-3,4-epoxide (6) was syn-
\end{abstract}

thesized in order to evaluate its role as the ultimate mutagenic active form of 1 . The epoxide 6 was a direct-acting mutagen. In addition, a pyrolysate containing a mixture of $1(85 \%), 2(2 \%)$, and 3 $(13 \%)$ obtained by flash vacuum thermolysis of 3 -(1-chloroethenyl)fluoranthene $(2 \mathrm{a})$ at $1,050^{\circ} \mathrm{C}$ was also mutagenic, but a significant mutagenic response was detected only in the presence of S9 activation. The results of this study indicate that 1 and 2 can contribute to the mutagenic activity of combustion exhausts. Environ. Mol. Mutagen. 44: 304-312, 2004. () 2004 Wiley-Liss, Inc.

Key words: nonalternant cyclopenta-fused polycyclic aromatic hydrocarbon; Salmonella typhimurium TA98; epoxidation; pyrolysate

\section{INTRODUCTION}

The genotoxicity associated with combustion exhausts is commonly attributed to the presence of polycyclic aromatic hydrocarbons (PAHs). PAHs are formed during incomplete combustion of fossil fuels and are widely distributed throughout our environment [Wiersum and Jenneskens, 1997; Mastral et al., 2000]. For instance, fluoranthene (3, Fig. 1) is one of the most abundant constituents of combustion exhausts and its concentration is greater than that of the most studied PAH, benzo[a]pyrene (B[a]P) [Lafleur et al., 1990]. Among the plethora of PAHs that are formed during incomplete combustion, the genotoxicity of combustion exhausts is generally determined by summation of the individual contributions made by 16 PAHs recommended by the U.S. Environmental Protection Agency [1997], which in general is then referred to the potency of $\mathrm{B}[\mathrm{a}] \mathrm{P}$. However, these chemicals cannot entirely account for the total genotoxicity of the PAHs present in combustion exhausts. Most probably, other bioactive PAHs present in combustion effluents that are not on the U.S. Environmental Protection Agency list, as well as still unidentified compounds, are also of importance. Hence, the identification of other genotoxic PAHs in combustion exhausts is a timely issue [Jacob, 1996].

Among the PAHs present under combustion conditions, cyclopenta-fused PAHs (CP-PAHs) represent a special subclass. These nonalternant PAHs, which possess at least one externally annelated unsaturated five-membered ring, are readily generated via accretion of $\mathrm{C}_{2}$ or $\mathrm{C}_{2} \mathrm{H}_{2}$ (ethyne) to PAH radicals, resulting in ethynyl-substituted PAHs (EPAHs) [Bockhorn et al., 1983; Wang and Frenklach, 1997; Bauschlicher and Ricca, 2000; Necula and Scott, 2000]. The facile conversion of suitable E-PAH precursors into CPPAHs under high-temperature conditions in the gas phase has been extensively investigated by our group using flash vacuum thermolysis (FVT) [Jenneskens et al., 1996, 1999; Jenneskens and Sarobe, 1999]. FVT not only is able to synthesize pure CP-PAHs, which are difficult to produce using classical wet chemical synthesis, but also provides product mixtures (so-called pyrolysates) that are partial mimics of combustion exhausts [Otero-Lobato et al., 2004a]. The proposed role of E-PAHs as penultimate pre-

*Correspondence to: Leonardus W. Jenneskens, Debye Institute, Depart-
ment of Physical Organic Chemistry, Utrecht University, Padualaan 8,
3584 CH Utrecht, The Netherlands. E-mail: 1.w.jenneskens@ @ chem.uu.nl

Received 12 May 2004; provisionally accepted 19 June 2004; and in final form 19 June 2004

DOI 10.1002/em.20047

Published online in Wiley InterScience (www.interscience.wiley.com). 
<smiles>C=C(Cl)c1ccc2c3c(cccc13)-c1ccccc1-2</smiles>

$2 a$

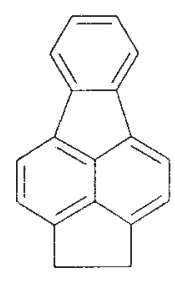

4<smiles>C#Cc1ccc2c3c(cccc13)-c1ccccc1-2</smiles>

2<smiles>CCc1ccc2c3c(cccc13)-c1ccccc1-2</smiles>

5

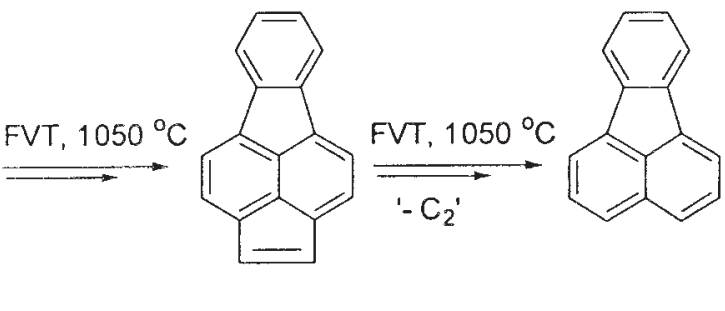

1

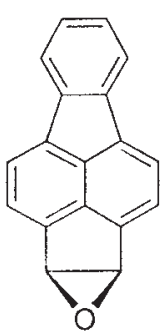

3
Fig. 1. Pyrolysate obtained by FVT $\left(\mathrm{p}<0.01 \mathrm{~mm} \mathrm{Hg}, \mathrm{T}=1,050^{\circ} \mathrm{C}\right.$ ) consisting of cyclopenta[cd]fluoranthene (1, 85\%), 3-ethynylfluoranthene $(2,2 \%)$, and fluoranthene $(3,13 \%)$, the partially hydrogenated derivatives 3,4-dihydrocyclopenta[cd]fluoranthene (4) and 3-ethylfluoranthene (5),

cursors for CP-PAHs is supported by their unequivocal identification in combustion exhausts [Lafleur et al., 1988, 1998; Ledesma et al., 1999].

CP-PAHs are also of interest because they generally exhibit unusual physicochemical properties [Koper et al., 2004] and, more important, they possess enhanced genotoxic properties when compared to their parent PAHs lacking the cyclopenta moiety. For example, one of the most studied CP-PAHs, cyclopenta[cd]pyrene, is a bacterial and mammalian cell mutagen, tumor promoter, and (co)carcinogen [Gold et al., 1980; Wood et al., 1980; Cavalieri et al., 1983; Lafleur et al., 1993; Busby et al., 1997]. In contrast, its parent $\mathrm{PAH}$, pyrene, is biologically inactive [Matijasevic and Zeiger, 1985]. Furthermore, cyclopenta[cd]pyrene and fluoranthene (3, Fig. 1) were previously proposed to be the main contributors to the total metabolism-dependent mutagenic activity found in the nonpolar fraction of combustion exhausts using a forward mutation assay [Lafleur et al., 1990]. Nevertheless, the amount of cyclopenta[cd]pyrene and fluoranthene (3) could not account for the total mutagenic response of the nonpolar fraction. Hence, still unidentified compounds must contribute to the total genotoxic potency. Recently, we assayed the bacterial mutagenicity of the three possible dicyclopenta-fused congeners of cyclopenta[cd]pyrene [Sarobe et al., 1995a], which were identified as constituents of the nonpolar fraction of combustion exhausts [Lafleur et al., 1996, 1998]. We found that all the dicyclopenta-fused pyrene congeners contribute to the bur- and cyclopenta[cd]fluoranthene-3,4-epoxide (6). Compounds 1-6 were assayed for mutagenicity in S. typhimurium strain TA98 using previously published protocols [Ames et al., 1975; Maron and Ames, 1983].

den of mutagenic activity. Interestingly, they exert a higher activity than cyclopenta[cd]pyrene [Otero-Lobato et al., 2004b]. This prompted us to study the mutagenic potency of another novel CP-PAH that was recently identified in combustion exhausts [Sarobe et al., 1995a; Lafleur et al., 1998; Ledesma et al., 1999], i.e., cyclopenta[cd]fluoranthene (1, Fig. 1).

Here, we report the mutagenic activity of the cyclopentafused congener of fluoranthene (3), i.e., cyclopenta[cd]fluoranthene (1), and 3-ethynylfluoranthene (2, Fig. 1), which is the anticipated thermal precursor of $\mathbf{1}$ under high-temperature combustion conditions. Assessment of the bacterial mutagenic response of $\mathbf{2}$ is also of interest from another perspective. Various E-PAHs are inhibitors of some of the isoenzymes of cytochrome $\mathrm{P} 450$ that are responsible for the oxidative metabolic activation of PAHs, namely, epoxide formation [Gan et al., 1984; Ortiz de Montellano and Reich, 1986; Hall et al., 1990]. Furthermore, an FVT-pyrolysate containing a mixture of compounds 1-3 (Fig. 1), which can be considered a partial mimic of combustion exhausts, was also assayed for mutagenic activity. Note that in a previous investigation, we found that the presence of E-PAHs in FVT-pyrolysates may greatly affect their global mutagenic response [Otero-Lobato et al., 2004a]. The importance of the unsaturated cyclopentano moiety and the ethynyl group in $\mathbf{1}$ and $\mathbf{2}$, respectively, to their mutagenic responses was evaluated by testing the partially hydrogenated derivatives 3,4-dihydrocyclopenta[cd]fluoranthene (4) and 3-ethylfluoranthene (5) (Fig. 1). It is frequently 
proposed that the ultimate mutagenic forms of CP-PAHs are the epoxides at the externally fused five-membered ring, which are obtained by a one-step oxidation process by cytochromes P450 present in exogenous activation mixtures (S9 mixes) [Gold and Eisenstadt, 1980; Gold et al., 1980]. Therefore, the monoepoxide derivative of $\mathbf{1}$, i.e., cyclopenta[cd]fluoranthene3,4-epoxide (6) (Fig. 1), was also synthesized and assayed for bacterial mutagenicity.

\section{MATERIALS AND METHODS}

\section{Test Compounds and Chemicals}

Cyclopenta[cd]fluoranthene (1, CAS 193-54-4), 3-ethynylfluoranthene (2, CAS 173066-87-0), 3,4-dihydrocyclopenta[cd]fluoranthene (4), 3-ethylfluoranthene (5, CAS 20496-16-6), and cyclopenta[cd]fluoranthene-3,4epoxide (6) were synthesized as described below. Fluoranthene (3, 98\%, CAS 206-44-0) was purchased from Aldrich (Milwaukee, WI) and purified by recrystallization from ethanol $(20 \mathrm{mg} / \mathrm{ml})$. The purity of all test compounds was $>98.9 \%$ (capillary GC). Benzo[a]pyrene (B[a]P, 98.8\%, CAS 50-32-8) and 1-nitropyrene (1-NP, 99\%, CAS 5522-43-0) were purchased from Sigma-Aldrich (St. Louis, MO) and used without further purification. Dimethyl sulfoxide (DMSO, 99.9\%, CAS 67-68-5) was purchased from Aldrich and NADP monosodium salt (98\%, CAS 1184-16-3), D-glucose6-phosphate anhydrous (G-6-P, 99\%, CAS 56-73-5), and potassium monopersulfate triple salt (caroate, CAS 37222-66-5) were from Sigma. $\mathrm{CP}-\mathrm{PAH}$ and their derivatives must be handled with care following the National Institutes of Health guidelines for carcinogens.

\section{Bacterial Mutagenicity Assays}

Mutagenicity was determined with the Salmonella/microsome (his) reversion assay using Salmonella typhimurium strain TA98 and following previously published protocols [Ames et al., 1975; Maron and Ames, 1983]. Assays were conducted both in the absence and in the presence of an exogenous metabolic activation system $( \pm \mathrm{S} 9 \mathrm{mix})$. The $\mathrm{S} 9 \mathrm{mix}$ consisted of a rat liver microsome preparation ( $\mathrm{S} 9$ fraction) obtained from Aroclor-1254-treated male Wistar rats and NADPH-generating cofactors [Maron and Ames, 1983]. The total protein content and the activity of the cytochrome P450 isoenzyme P450-1A were determined as $29.15 \mathrm{mg} / \mathrm{ml}$ (Lowry method) [Lowry et al., 1951] and $51.58 \mathrm{pmol} / \mathrm{ml} / \mathrm{min} / \mathrm{mg}$ protein (EROD method) [Wortelboer et al., 1990], respectively.

Compounds 1-5 were dissolved at $500 \mu \mathrm{g} / \mathrm{ml}$ in DMSO and tested at $1.0,5.0,15.0$, and $20.0 \mu \mathrm{g} / \mathrm{plate}$ in a constant volume of $100 \mu \mathrm{l} / \mathrm{plate}$ of DMSO. Compound 6 was tested only up to $2.0 \mu \mathrm{g} / \mathrm{plate}$ due to its relatively high cytotoxicity. Three plates were employed both in the absence $(-\mathrm{S} 9$ $\mathrm{mix})$ and in the presence of a metabolic activation mixture $[+\mathrm{S} 9 \mathrm{mix}$, standard $4 \%(\mathrm{v} / \mathrm{v})$ and $2 \%(\mathrm{v} / \mathrm{v}), 0.58$ and $0.29 \mathrm{mg}$ protein/plate, respectively] for every concentration in at least two independent series of experiments. Positive controls, i.e., 1-NP, $5.0 \mu \mathrm{g} /$ plate $(-\mathrm{S} 9 \mathrm{mix},>1,000$ revertants/plate), and B[a]P, $6.0 \mu \mathrm{g} /$ plate [for example, with $2 \%$ (v/v) S9 mix, $133.9 \pm 20.5$ revertants/plate], and negative controls, i.e., DMSO $(-\mathrm{S} 9 \mathrm{mix}, 10.2 \pm 4.7 ;+\mathrm{S} 9 \mathrm{mix}, 19.8 \pm 6.5$ revertants/plate) and spontaneous $\mathrm{his}^{+}$reversion $(-\mathrm{S} 9 \mathrm{mix}, 13.3 \pm 4.7 ;+\mathrm{S} 9 \mathrm{mix}, 21.6 \pm 6$ revertants/plate), were included in each experiment. The plates were incubated at $37^{\circ} \mathrm{C}$ for $48 \mathrm{hr}$ and the his ${ }^{+}$revertants counted manually. The results obtained in the bacterial mutagenicity assays are presented as dose-response curves and are expressed as mean values of $h i s^{+}$revertants per dose of test compound from three different plates from two independent experiments with no correction for spontaneous $h i s^{+}$revertants. The standard deviation (from six plates) is expressed as error bars (see Tables I-III for the primary data).

The following criteria for positive mutagenic activity were used to
TABLE I. Mutagenic Activity of Cyclopenta[cd]fluoranthene (1) Using the Salmonella typhimurium Strain TA98 Without (-S9 Mix) and With Exogenous Metabolic Activation Mixture (+S9 Mix $)^{\mathrm{a}}$

\begin{tabular}{lccc}
\hline & & $+2 \%(\mathrm{v} / \mathrm{v})$ & $+4 \%(\mathrm{v} / \mathrm{v})$ \\
& & $\mathrm{S} 9$ mix & $\mathrm{S} 9$ mix \\
\hline $\begin{array}{l}\text { Concentration, } \\
\mu \mathrm{g} / \text { plate }\end{array}$ & & & \\
0.0 & $9 \pm 5.6$ & $18.3 \pm 4.3$ & $40.3 \pm 11.2$ \\
1.0 & $11.8 \pm 6.3$ & $20.3 \pm 2.7$ & $41.3 \pm 7.8$ \\
5.0 & $11.3 \pm 7$ & $41 \pm 7.8$ & $52.8 \pm 20.5$ \\
15.0 & $14.5 \pm 4.5$ & $56.5 \pm 9.8$ & $66.6 \pm 13.1$ \\
20.0 & $23.3 \pm 13.2$ & $69.3 \pm 8.7$ & $98.5 \pm 5.5$ \\
his $^{+}$revertants/ & $\sim 0.05(0.72)$ & $0.6(0.96)$ & $0.7(0.98)$ \\
nmol $\left(\mathrm{r}^{2}\right)$ & & & \\
\hline
\end{tabular}

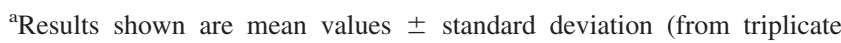
plates for each dose in two independent experiments) and are given in $\mathrm{his}^{+}$ revertants per plate without correction for background; $2 \%(\mathrm{v} / \mathrm{v})$, i.e., $0.29 \mathrm{mg}$ protein/plate and standard $4 \%(\mathrm{v} / \mathrm{v})$, i.e., $0.58 \mathrm{mg}$ protein/plate.

establish a positive response [Claxton et al., 1987; Kim and Margolin, 1999; Mortelmans and Zeiger, 2000]: threefold increase of his ${ }^{+}$revertants in plates with test compound as compared to the negative control (DMSO); ascending dose-response behavior; and replication of results in at least two independent experiments. The three criteria were used because employing the threefold rule alone is not considered sufficient for establishing an unambiguous positive mutagenic response [Cariello and Piegorsh, 1996]. The specific mutagenic activities, i.e., number of $\mathrm{his}^{+}$revertants induced per nmol of test compound, were calculated by least-squares regression from the initial ascending linear portion of the dose-response curves (Table IV). Tables I-III show the primary data (mean his $^{+}$revertants \pm standard deviation) and the correlation coefficients $\left(\mathrm{r}^{2}\right)$ derived from calculation of the specific mutagenic activities.

\section{Synthesis}

All reactions except the epoxidation were carried out under an $\mathrm{N}_{2}$ atmosphere. Solvents were dried and purified using standard protocols. Commercial reagents were used as received if not otherwise indicated. Flash column chromatography was performed either on Merk kieselgel 60 silica (230-400 ASTM) or neutral aluminium oxide W200. Thin-layer chromatography (TLC) was carried out using TLC aluminium sheets [aluminium oxide $60 \mathrm{~F}_{254}$ neutral (type E) or TLC silica gel $60 \mathrm{~F}_{254}$ ]. Melting points are uncorrected. ${ }^{1} \mathrm{H}$ and ${ }^{13} \mathrm{C}$ NMR spectra were recorded on either a Bruker AC 300 or a Varian Unity Inova Spectrometer operating at 300.13 and $75.47 \mathrm{MHz}$, respectively, at $25^{\circ} \mathrm{C}$; either $\mathrm{d}_{6}$-acetone, $\mathrm{CD}_{2} \mathrm{Cl}_{2}$, or $\mathrm{CDCl}_{3}$ was used as solvents. ${ }^{1} \mathrm{H}$ and ${ }^{13} \mathrm{C}$ chemical shift values are reported in ppm using tetramethylsilane (TMS) as a reference. J-values are given in $\mathrm{Hz}$ (multiplicity: $\mathrm{s}=$ singlet, $\mathrm{d}=$ doublet, $\mathrm{t}=$ triplet, $\mathrm{dd}=$ double doublet, and $\mathrm{m}=$ multiplet). Capillary GC chromatograms were measured on a Varian GC 3350 or Varian GC 3400: capillary column DB 5 (length $30 \mathrm{~m}$, ID $0.3 \mathrm{~mm}$, and $1 \mu \mathrm{m}$ film thickness), temperature program $\left(\mathrm{T}_{\mathrm{i}}=\right.$ 200 or $250^{\circ} \mathrm{C}$, isothermal for $10 \mathrm{~min}$, heating to $280^{\circ} \mathrm{C}$ at $10^{\circ} \mathrm{C} / \mathrm{min}$ ), injector and detector temperature $300^{\circ} \mathrm{C}$, and $\mathrm{He}$ as carrier gas. GC-MS spectra were measured on an ATI Unicam Automass System 2 quadrople mass spectrometer: J\&W Scientific DB-15 ms capillary column (length $30 \mathrm{~m}$, ID $0.25 \mathrm{~mm}$, and $0.25 \mathrm{~mm}$ film thickness), temperature program $\left(\mathrm{T}_{\mathrm{i}}=200\right.$ or $250^{\circ} \mathrm{C}$, isothermal for $10 \mathrm{~min}$, heating to $280^{\circ} \mathrm{C}$ at $10^{\circ} \mathrm{C} / \mathrm{min}$ ), injector and detector temperature $300^{\circ} \mathrm{C}$, and $\mathrm{He}$ as carrier gas; mass spectrometer $(\mathrm{MS})=\mathrm{EI} 70 \mathrm{eV}$. CP-PAH and derivatives must be handled according to the National Institutes of Health guidelines for carcinogens 
TABLE II. Bacterial Mutagenic Activity of 3-Ethynylfluoranthene (2), Fluoranthene (3), and the Pyrolysate Containing of Cyclopenta[cd]fluoranthene $1(85 \%), 2(2 \%)$, and $3(13 \%)^{\mathrm{a}}$

\begin{tabular}{|c|c|c|c|c|c|c|}
\hline & \multicolumn{2}{|c|}{2} & \multicolumn{2}{|c|}{3} & \multicolumn{2}{|c|}{ Pyrolysate } \\
\hline & $\begin{array}{c}+2 \%(\mathrm{v} / \mathrm{v}) \\
\mathrm{S} 9 \mathrm{mix}\end{array}$ & $-\mathrm{S} 9 \operatorname{mix}$ & $\begin{array}{c}+4 \%(\mathrm{v} / \mathrm{v}) \\
\mathrm{S} 9 \mathrm{mix}\end{array}$ & $-\mathrm{S} 9 \operatorname{mix}$ & $\begin{array}{c}+2 \%(\mathrm{v} / \mathrm{v}) \\
\mathrm{S} 9 \mathrm{mix}\end{array}$ & $-\mathrm{S} 9 \mathrm{mix}$ \\
\hline \multicolumn{7}{|l|}{ Concentration, $\mu \mathrm{g} /$ plate } \\
\hline 0.0 & $25.5 \pm 6.80$ & $15.5 \pm 7.50$ & $16.5 \pm 4.50$ & $12 \pm 1$ & $26 \pm 6.80$ & $20 \pm 7.50$ \\
\hline 1.0 & $59 \pm 19.60$ & $30 \pm 5.40$ & $27.5 \pm 0.50$ & $23.5 \pm 2.5$ & $34 \pm 10.50$ & $29 \pm 4.40$ \\
\hline 5.0 & $65 \pm 10.80$ & $62 \pm 6.40$ & $29 \pm 2.00$ & $21 \pm 5$ & $62 \pm 8.60$ & $38 \pm 0.80$ \\
\hline 15.0 & $100 \pm 22.30$ & $124 \pm 4.30$ & $24 \pm 5.00$ & $19 \pm 1.0$ & $84 \pm 7.90$ & $54 \pm 8.50$ \\
\hline 20.0 & $175.5 \pm 17.80$ & $150 \pm 15.10$ & $15.5 \pm 1.5$ & $20 \pm 1$ & $80 \pm 11.70$ & $63 \pm 9.70$ \\
\hline$h i s^{+}$revertants $/ \mathrm{nmol}\left(\mathrm{r}^{2}\right)$ & $1.4(0.98)$ & $1.5(0.99)$ & & & $0.9(0.92)$ & $0.5(0.92)$ \\
\hline
\end{tabular}

${ }^{a}$ Employing the Salmonella typhimurium strain TA98, with and without exogenous metabolic activation mixture ( \pm S9 mix). Results shown are mean values \pm standard deviation (from triplicate plates for each dose in two independent experiments) and are given in $h_{i s}{ }^{+}$revertants per plate without correction for spontaneous his $^{+}$revertants.

TABLE III. Bacterial Mutagenic Activity of 3,4-Dihydrocyclopenta[cd]fluoranthene (4), 3-Ethylfluoranthene (5), and Cyclopenta[cd]fluoranthene-3,4-epoxide $(6)^{\text {a }}$

\begin{tabular}{|c|c|c|c|c|c|c|c|}
\hline & \multicolumn{2}{|c|}{4} & \multicolumn{2}{|c|}{5} & & \multicolumn{2}{|c|}{6} \\
\hline & $+2 \%(\mathrm{v} / \mathrm{v})$ & & $+4 \%(\mathrm{v} / \mathrm{v})$ & & & $+2 \%(\mathrm{v} / \mathrm{v})$ & \\
\hline & S9 mix & $-\mathrm{S} 9 \operatorname{mix}$ & S9 mix & $-\mathrm{S} 9 \operatorname{mix}$ & & S9 mix & $-\mathrm{S} 9 \operatorname{mix}$ \\
\hline Concentration, $\mu \mathrm{g} / \mathrm{plate}$ & & & & & Concentration, $\mu \mathrm{g} / \mathrm{plate}$ & & \\
\hline 0.0 & $25.5 \pm 6.8$ & $20 \pm 7.5$ & $25.5 \pm 6.8$ & $20 \pm 7.5$ & 0.0 & $21.8 \pm 4.70$ & $7.5 \pm 2.60$ \\
\hline 1.0 & $20 \pm 3.4$ & $24.3 \pm 2.6$ & $23.5 \pm 3.0$ & $25.8 \pm 5.4$ & 0.1 & $15.5 \pm 8.20$ & $13.8 \pm 3.40$ \\
\hline 5.0 & $25.8 \pm 5.3$ & $27 \pm 5.3$ & $22 \pm 8.8$ & $20 \pm 1.4$ & 0.5 & $17.3 \pm 4.10$ & $21.3 \pm 7.30$ \\
\hline 15.0 & $28.8 \pm 4.0$ & $30 \pm 5.0$ & $26 \pm 3.8$ & $17.5 \pm 1.1$ & 1.5 & $24.5 \pm 5.40$ & $25.5 \pm 14.50$ \\
\hline 20.0 & $27.5 \pm 4.4$ & $29 \pm 4.6$ & $29.5 \pm 4.8$ & $24.8 \pm 2.7$ & 2.0 & $35.5 \pm 5.60$ & $43 \pm 7.40$ \\
\hline his $^{+}$revertants $/ \mathrm{nmol}\left(\mathrm{r}^{2}\right)$ & & & & & his $^{+}$revertants/nmol $\left(\mathrm{r}^{2}\right)$ & $1.6(0.63)$ & $4.1(0.92)$ \\
\hline
\end{tabular}

${ }^{a}$ Employing the Salmonella typhimurium strain TA98, with and without exogenous metabolic activation mixture ( \pm S9 mix). Results shown are mean values \pm standard deviation (from triplicate plates for each dose in two independent experiments) and are given in is $^{+}$revertants per plate without correction for spontaneous his $^{+}$revertants.

TABLE IV. Specific Mutagenic Activities $\left(\right.$ his $^{+}$Revertants/nMol) and Mutagenic Potency of 1-6 and the FVT-Pyrolysate Obtained in the Synthesis of $1^{\mathrm{a}}$

\begin{tabular}{|c|c|c|c|c|}
\hline & \multicolumn{2}{|c|}{ TA98 + 2\% (v/v) S9 mix } & \multicolumn{2}{|c|}{ TA98 -S9 mix } \\
\hline & $\begin{array}{c}\text { his }^{+} \text {revertants/ } \\
\text { nmol }\end{array}$ & $\begin{array}{c}\text { Mutagenic } \\
\text { potency }\end{array}$ & $\begin{array}{c}\text { his }^{+} \text {revertants/ } \\
\text { nmol }\end{array}$ & $\begin{array}{c}\text { Mutagenic } \\
\text { potency }\end{array}$ \\
\hline \multicolumn{5}{|l|}{ Compound } \\
\hline 1 & $0.7\left(0.8^{\mathrm{b}}\right)$ & $+1-$ & 0.1 & - \\
\hline 2 & 1.4 & + & 1.5 & + \\
\hline 3 & $\sim 0.05\left(\sim 0.05^{\mathrm{b}}\right)$ & - & $\sim 0.05$ & - \\
\hline 4 & $\sim 0.05$ & - & $\sim 0.05$ & - \\
\hline 5 & $\sim 0.05$ & - & $\sim 0.05$ & - \\
\hline 6 & 1.6 & + & 4.1 & + \\
\hline FVT-pyrolysate & $0.9\left(0.9^{b}\right)$ & $+1-$ & 0.5 & - \\
\hline
\end{tabular}

${ }^{a}$ Calculated by least squares regression from the ascending linear portion of dose-response curves (Figs. 3-6). For 1-5, the dose range $0.0-20.0 \mu \mathrm{g} /$ plate was used. Perceived mutagenic potency: - , negative; $+/-$, weakly positive; + , positive.

${ }^{\mathrm{b}}$ With standard $4 \%(\mathrm{v} / \mathrm{v}) \mathrm{S} 9$ mix.

due to their potential genotoxicity. Dimethyldioxirane is a volatile peroxide and must be synthesized and used with caution.

\section{FVT-Pyrolysate and Cyclopenta[cd]fluoranthene (1)}

Cyclopenta[cd]fluoranthene (1) and its corresponding FVT-pyrolysate (mixture of $\mathbf{1}+\mathbf{2}+\mathbf{3}$ ) were obtained employing FVT as described previously [Sarobe et al., 1995b]. A commercial Thermolyne 21100 tube furnace containing an unpacked quartz tube $(40 \mathrm{~cm}$ length, $2.5 \mathrm{~cm}$ diameter) was used at $\mathrm{T}=1,050^{\circ} \mathrm{C}, \mathrm{p}<0.01 \mathrm{~mm} \mathrm{Hg}$. The pyrolysate, which deposited behind the hot zone, was recovered from the tube with an aliquot of dry $\mathrm{CH}_{2} \mathrm{Cl}_{2}(\sim 3 \mathrm{ml})$ and subjected to spectral analysis before further purification. The FVT-pyrolysate consisted of cyclopenta[cd]fluoranthene (1, 85\%), 3-ethynylfluoranthene $(2,2 \%)$, and fluoranthene $(3,13 \%)$; the 
mass recovery was $\sim 85 \%$. The presence of $\mathbf{3}$ is explained by invoking $\mathrm{C}_{2}$ extrusion from 1 under the high-temperature conditions used (Fig. 1) [Sarobe et al., 1995b, 1999].

Compound 1 was isolated from the pyrolysate after flash chromatography using $n$-hexane as the eluent. After removal of the solvent in vacuo, the solid residue was recrystallized from ethanol $(15 \mathrm{mg} / \mathrm{ml})$ at $\mathrm{T}=-20^{\circ} \mathrm{C}$. Pure 1 was isolated as (large) red needles; its ${ }^{1} \mathrm{H}$ and ${ }^{13} \mathrm{C}$ NMR spectral data were in accordance with previously reported data [Sarobe et al., 1995b]. The pyrolysate, which resembles part of a combustion exhaust, was also independently assayed for mutagenicity.

\section{Independent Synthesis of 3-Ethynylfluoranthene (2)}

3-(1-chloroethenyl)fluoranthene (2a) was prepared as described previously [Sarobe et al., 1995b]. To a cooled suspension $\left(-40^{\circ} \mathrm{C}\right)$ of $\mathrm{Na}$ $(0.25 \mathrm{~g}, 0.01 \mathrm{mmol})$ dissolved in $45 \mathrm{ml}$ of liquid ammonia, a solution of $\mathbf{2 a}$ $(0.5033 \mathrm{~g}, 1.92 \mathrm{mmol})$ in $20 \mathrm{ml}$ dry THF was slowly added drop-wise. After stirring for $8 \mathrm{hr}$ at $-35^{\circ} \mathrm{C}$, the temperature of the reaction mixture was slowly raised to room temperature. The ammonia was evaporated and $150 \mathrm{ml}$ of $1 \mathrm{M} \mathrm{H}_{2} \mathrm{SO}_{4}$ was added. Subsequently, the reaction mixture was extracted with $\mathrm{CH}_{2} \mathrm{Cl}_{2}(4 \times 60 \mathrm{ml})$. The combined organic fractions were dried over $\mathrm{MgSO}_{4}$, filtered, and the filtrate was subsequently concentrated in vacuo furnishing pure 3-ethynylfluoranthene [2; yield $0.425 \mathrm{~g}$ (1.88 mmol, $98 \%$ ), dark-orange solid]. M.p. $76-78^{\circ} \mathrm{C} . \delta_{\mathrm{H}}\left(\mathrm{CD}_{2} \mathrm{Cl}_{2}\right): 8.14$ (1H, d, J 8.3), $7.96\left(1 \mathrm{H}, \mathrm{d} \mathrm{J}\right.$ 6.9), 7.91-7.87 $\left(4 \mathrm{H}, \mathrm{m}\right.$, also contains the $\mathrm{AA}^{\prime}$ part of the $\mathrm{AA}^{\prime} \mathrm{XX}^{\prime}$ system $), 7.70(1 \mathrm{H}, \mathrm{dd}, \mathrm{J} 8.3, \mathrm{~J} 6.9), 7.43(2 \mathrm{H}, \mathrm{m}$, the $\mathrm{XX}^{\prime}$ part of the $\mathrm{AA}^{\prime} \mathrm{XX}^{\prime}$ system), and $3.59(1 \mathrm{H}, \mathrm{s}) . \delta_{\mathrm{C}}\left(\mathrm{CD}_{2} \mathrm{Cl}_{2}\right): 140.0$, 139.1, 138.1, 137.5, 133.4, 132.4, 130.9, 129.2, 128.5, 128.1, 125.3, 122.2, 122.0, 121.1, 119.8, 119.5, 82.7, 81.5. m/z (MS): $226\left(\mathrm{M}^{\cdot+} ; 100\right), 198(8)$, 113 (27).

\section{Fluoranthene (3)}

Commercial fluoranthene (3) was purified by recrystallization from ethanol $(20 \mathrm{mg} / \mathrm{ml})$. Pure fluoranthene $(3)$ was isolated as large white needles. M.p. $109-111^{\circ} \mathrm{C} . \delta_{\mathrm{H}}\left(\mathrm{CDCl}_{3}\right): 7.96(2 \mathrm{H}, \mathrm{d}, \mathrm{J} 6.9), 7.85-7.79(2 \mathrm{H}$, $\mathrm{m}$, the $\mathrm{AA}^{\prime}$ part of the $\mathrm{AA}^{\prime} \mathrm{XX}^{\prime}$ system), $7.81(2 \mathrm{H}, \mathrm{d}, \mathrm{J} 8.2), 7.61-7.56(2 \mathrm{H}$ $\mathrm{dd}, \mathrm{J} 8.2, \mathrm{~J} 6.9)$, and $7.38-7.32\left(2 \mathrm{H}, \mathrm{m}\right.$, the $\mathrm{XX}^{\prime}$ part of the $\mathrm{AA}^{\prime} \mathrm{XX}^{\prime}$ system). $\delta_{\mathrm{C}}\left(\mathrm{CDCl}_{3}\right): 139.5,137.0,132.4,130.0,128.0,127.6,126.7$, 121.6, and 120.1. GC-MS m/z (relative intensity): $202\left(\mathrm{M}^{{ }^{+}}{ }^{+} ; 100\right)$, 101 (12).

\section{3,4-Dihydrocyclopenta[cd]fluoranthene (4) and 3- Ethylfluoranthene (5)}

\begin{abstract}
3,4-dihydrocyclopenta[cd]fluoranthene (4) and 3-ethylfluoranthene (5) were obtained by catalytic hydrogenation of cyclopenta[cd]fluoranthene (1) and 3-ethynylfluoranthene $(2)$, respectively $(\sim 10 \mathrm{mmol})$, with hydrogen $\left(\mathrm{p}_{\mathrm{H} 2}\right.$ $1 \mathrm{~atm})$ and $2 \mathrm{mg}$ Pd on activated carbon in $15 \mathrm{ml}$ dry THF at room temperature. The hydrogenation reaction was completed when the intense color of the reactant solution had disappeared ( $2-3 \mathrm{hr})$. The reaction mixture was filtered over Celite followed by concentration of the filtrate in vacuo, giving either pure $\mathbf{4}$ or $\mathbf{5}$ as colorless solids in near quantitative yield.
\end{abstract}

\section{3,4-Dihydrocyclopenta[cd]fluoranthene (4)}

White solid. M.p. $148-150^{\circ} \mathrm{C} . \delta_{\mathrm{H}}\left(\mathrm{CDCl}_{3}\right): 7.99-7.93\left(2 \mathrm{H}, \mathrm{m}\right.$, the $\mathrm{AA}^{\prime}$ part of the $\mathrm{AA}^{\prime} \mathrm{XX}^{\prime}$ system), $7.47(2 \mathrm{H}, \mathrm{d}, \mathrm{J} 6.9), 7.40-7.38(2 \mathrm{H}, \mathrm{m}$, the $\mathrm{XX}^{\prime}$ part of the $\mathrm{AA}^{\prime} \mathrm{XX}^{\prime}$ system $)$, and $3.54(4 \mathrm{H}, \mathrm{s}) . \delta_{\mathrm{C}}\left(\mathrm{CDCl}_{3}\right): 145.9$, 140.2, 139.5, 132.7, 131.1, 126.8, 122.1, 122.0, 120.5, and 32.4. GC-MS: $\mathrm{m} / \mathrm{z}$ (relative intensity) $228\left(\mathrm{M}^{*}+100\right), 113(35)$.

\section{3-Ethylfluoranthene (5)}

Pale beige solid. M.p. $75-76^{\circ} \mathrm{C} . \delta_{\mathrm{H}}\left(\mathrm{CDCl}_{3}\right): 8.02(1 \mathrm{H}, \mathrm{d}, \mathrm{J} 8.3), 7.95$ $(1 \mathrm{H}, \mathrm{d}, \mathrm{J} 6.9), 7.91-7.86\left(2 \mathrm{H}, \mathrm{m}\right.$, the $\mathrm{AA}^{\prime}$ part of the $\mathrm{AA}^{\prime} \mathrm{XX}^{\prime}$ system $)$, 7.67-7.61 $\left(2 \mathrm{H}, \mathrm{m}\right.$, the $\mathrm{AA}^{\prime}$ part of the $\mathrm{AA}^{\prime} \mathrm{XX}^{\prime}$ system), $7.45(1 \mathrm{H}, \mathrm{d}, \mathrm{J} 6.9)$, 7.37-7.34 (2H, m, the $\mathrm{XX}^{\prime}$ part of the $\mathrm{AA}^{\prime} \mathrm{XX}^{\prime}$ system), $3.23(2 \mathrm{H}, \mathrm{q}, \mathrm{J} 7.5)$, and $1.46\left(3 \mathrm{H}, \mathrm{t}, \mathrm{J}\right.$ 7.5). $\Delta_{\mathrm{C}}\left(\mathrm{CDCl}_{3}\right): 141.7,139.4,139.4,137.4,135.1$, $132.8,129.1,127.5,127.4,127.0,126.5,123.5,121.4,121.1,120.3,119.7$, 25.3, and 16.1. GC-MS: $\mathrm{m} / \mathrm{z}$ (relative intensity) $230\left(\mathrm{M}^{{ }^{+}+}\right.$; 50), 215 (100).

\section{Cyclopenta[cd]fluoranthene-3,4-Epoxide (6)}

Epoxidation of $\mathbf{1}$ was carried out using a freshly prepared solution of dimethyldioxirane in acetone. The dimethyldioxirane solution was prepared by dissolving solid caroate (triple salt of potassium monopersulfate) in a cold solution of $\mathrm{NaHCO}_{3}$ in acetone/water following literature procedures [Adam et al., 1991; Murray and Singh, 1997]. Usually, 50-70 ml of 0.07-0.10 M dimethyldioxirane in acetone were obtained. The dimethyldioxirane content was assayed by oxidation of methyl phenyl sulfide and monitoring its sulfoxide formation by calibrated capillary GC [Adam et al., 1991; Murray and Singh, 1997]. The dimethyldioxirane solution was stored at $-20^{\circ} \mathrm{C}$ over $3 \AA$ activated molecular sieves prior to use.

To a suspension of cyclopenta[cd]fluoranthene $1(7.4 \mathrm{mg}, 0.0327 \mathrm{mmol})$ and $20 \mathrm{mg}$ sodium bicarbonate in $3 \mathrm{ml}$ dry acetone, $2 \mathrm{ml}$ of a dimethyldioxirane solution $(0.071 \mathrm{M})$ was added, and the reaction mixture was stirred at room temperature in the dark for $8 \mathrm{hr}$. After total consumption of CP-PAH 1 (GC), the reaction mixture was filtered and the solvent removed in vacuo. The residue was dissolved in dry $\mathrm{CH}_{2} \mathrm{Cl}_{2}$, dried over $\mathrm{MgSO}_{4}$, and the solution filtered. Concentration of the filtrate in vacuo gave a beige waxy solid (7 mg, yield $88.5 \%$ ) that was identified as the analytically pure epoxide 6. $\delta_{\mathrm{H}}\left(\mathrm{d}_{6}\right.$-acetone) $7.96-7.94\left(2 \mathrm{H}, \mathrm{m}\right.$, the $\mathrm{AA}^{\prime}$ part of the $\mathrm{AA}^{\prime} \mathrm{XX}^{\prime}$ system), $7.82\left(4 \mathrm{H}, \mathrm{AB}\right.$ system, $\delta_{\mathrm{A}} 7.90$ and $\left.\delta_{\mathrm{B}} 7.74, \mathrm{~J}_{\mathrm{AB}} 7.0\right), 7.40-7.37$ $\left(2 \mathrm{H}, \mathrm{m}\right.$, the $\mathrm{XX}^{\prime}$ part of the $\mathrm{AA}^{\prime} \mathrm{XX}^{\prime}$ system $), 4.88(2 \mathrm{H}, \mathrm{s}) . \delta_{\mathrm{C}}\left(\mathrm{d}_{6}\right.$-acetone): $141.5,140.5,137.3,136.9,132.8,128.9,125.2,123.7,122.0,59.2$. GCMS: m/z (relative intensity) $242\left(\mathrm{M}^{\cdot+}, 60\right), 214$ (100), 213 (75), 121 (12), 187 (12), 107 (15). Presumably, epoxide 6 rearranges to 3,4-dihydrocyclopenta[cd]fluoranthen-3-one under the GC-MS conditions used [Sarobe, 1998].

\section{RESULTS}

The mutagenic responses of cyclopenta[cd]fluoranthene (1), 3-ethynylfluoranthene (2), fluoranthene (3), the pyrolysate containing $\mathbf{1}(85 \%), \mathbf{2}$ (2\%), and $\mathbf{3}$ (13\%), 3,4-dihydrocyclopenta[cd]fluoranthene (4), 3-ethylfluoranthene (5), and cyclopenta[cd]fluoranthene-3,4-epoxide (6, Fig. 1) were determined in the Salmonella/microsome assay using S. typhimurium tester strain TA98. Assays were conducted both without exogenous activation and with an S9 mix containing either $4 \%$ or $2 \%(\mathrm{v} / \mathrm{v})$ rat liver S9, i.e., 0.58 and $0.29 \mathrm{mg}$ protein/plate, respectively [Ames et al., 1975; Maron and Ames, 1983]. Mutagenic activity is shown as dose-response curves in Figures 2-6. The specific mutagenic activity of each compound was calculated, i.e., the number of $\mathrm{his}^{+}$ revertants produced per nmol of test compound, and the results are reported in Table IV. The primary data are reported in Tables I-III.

Figure 2 shows the mutagenic activity of $\mathbf{1}$ in the absence $(-\mathrm{S} 9 \mathrm{mix})$ and in the presence of both a standard $4 \%(\mathrm{v} / \mathrm{v})$ S9 mix as well as with a low-protein-content $2 \%(\mathrm{v} / \mathrm{v}) \mathrm{S} 9$ 


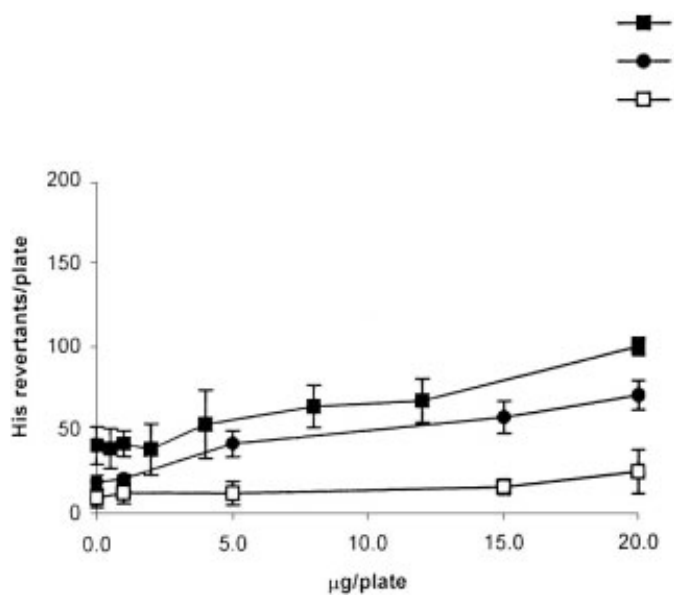

Fig. 2. Dose-response curves for the mutagenicity of cyclopenta[cd]fluoranthene (1) in S. typhimurium strain TA98 in the presence of $2 \%(\mathrm{v} / \mathrm{v}) \mathrm{S} 9$ mix (filled square) or standard 4\% (v/v) S9 mix (filled circle) and in the absence of exogenous metabolic activation (open square, $-\mathrm{S} 9 \mathrm{mix}$ ).

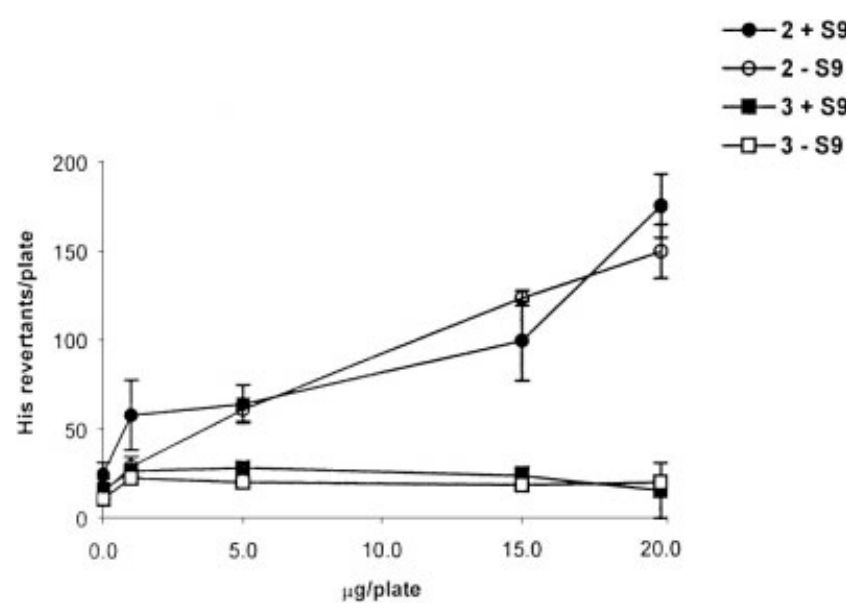

Fig. 3. Dose-response mutagenicity of 3-ethynyl fluoranthene (2; filled circle, $+\mathrm{S} 9 \mathrm{mix}$; open circle, $-\mathrm{S} 9 \mathrm{mix}$ ) and fluoranthene (3; filled square, $+\mathrm{S} 9$ mix; open square, $-\mathrm{S} 9 \mathrm{mix}$ ) in $S$. typhimurium strain TA98 with and without $2 \%(\mathrm{v} / \mathrm{v}) \mathrm{S} 9$ mix.

mix. Although 1 was mutagenic with both S9 protein concentrations, its activity was moderate (specific mutagenic activity 0.8 and 0.7 revertants/nmol, respectively; Table IV). Compound 1 was nonmutagenic without the S9 activation mixture. The metabolism-dependent mutagenic potency of $\mathbf{1}$ appears to be effectively independent of the protein content in the activation mixture, at least with $2 \%$ or $4 \%$ (v/v) S9. Thus, the low-protein-content S9 mix was chosen for further experiments.

Unexpectedly, 3-ethynylfluoranthene (2) was mutagenic both with and without $S 9$, with specific mutagenic activities of 1.4 and 1.5 revertants/nmol, respectively (Fig. 3, Table IV). In contrast, fluoranthene (3) did not exhibit mutagenic activity under our experimental conditions (with and without S9 mix using S. typhimurium strain TA98). The importance of the five-membered ring containing the ole-

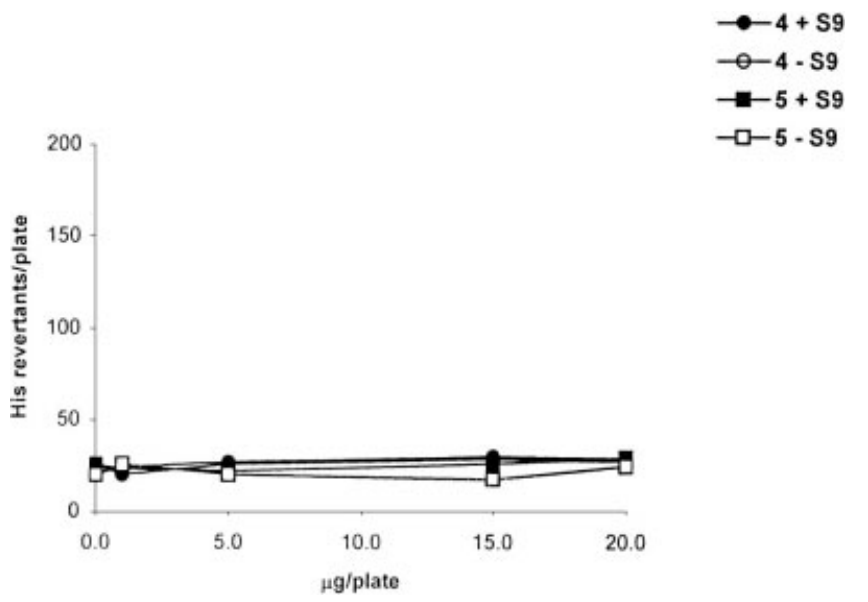

Fig. 4. Dose-response mutagenicity of the partially hydrogenated derivatives 3,4-dihydrocyclopenta[cd]fluoranthene (4; filled circle, +S9 mix; open circle, $-\mathrm{S} 9 \mathrm{mix})$ and 3 -ethylfluoranthene (5; filled square, $+\mathrm{S} 9$ mix; open square, $-\mathrm{S} 9 \mathrm{mix})$ in $S$. typhimurium strain TA98 with and without $2 \%(\mathrm{v} / \mathrm{v}) \mathrm{S} 9 \mathrm{mix}$

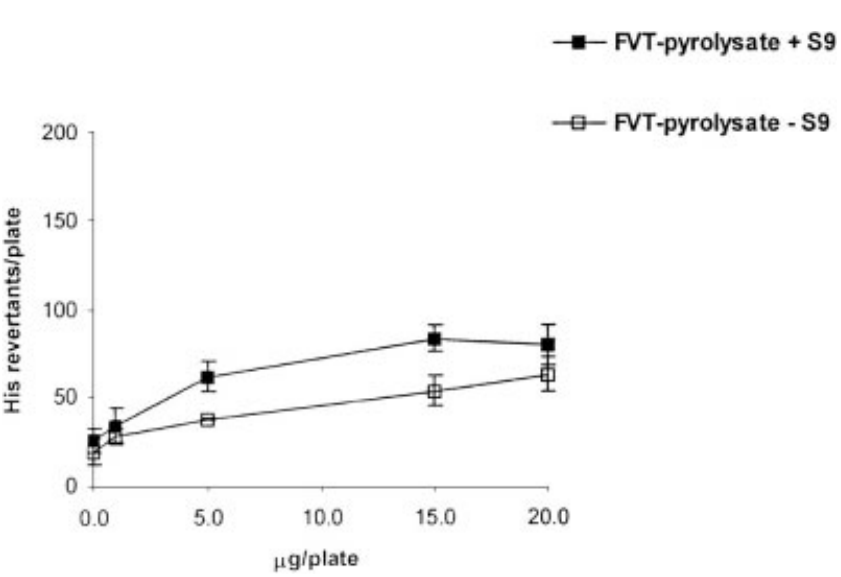

Fig. 5. Dose-response mutagenicity of the FVT-pyrolysate containing cyclopenta[cd]fluoranthene $(\mathbf{1}, 85 \%)$, 3-ethynylfluoranthene $(\mathbf{2}, 2 \%)$, and fluoranthene (3, 13\%; Fig. 1.) in S. typhimurium strain TA98 in the presence of $2 \%(\mathrm{v} / \mathrm{v}) \mathrm{S} 9$ mix (filled square) and in the absence of exogenous metabolic activation (open square, $-\mathrm{S} 9 \mathrm{mix}$ ).

finic bond for the mutagenicity of $\mathbf{1}$ and the ethynyl moiety for the mutagenicity of $\mathbf{2}$ was supported by the mutagenic activities of their corresponding partially hydrogenated derivatives, i.e., compounds $\mathbf{4}$ and $\mathbf{5}$, respectively. Both $\mathbf{4}$ and 5 were nonmutagenic (Fig. 4).

The FVT-pyrolysate containing $85 \% \mathbf{1}, 2 \% \mathbf{2}$, and $13 \%$ 3 was also tested and found to have an S9-dependent specific mutagenic activity slightly higher $(0.9$ revertants/nmol) than that of pure 1. Furthermore, the mixture exhibited a weak direct-acting mutagenic response that was negative under our criteria $(0.5$ revertants $/ \mathrm{nmol}$; Fig. 5, Table IV).

Since most ultimate mutagenic forms of CP-PAHs are epoxides at the cyclopentano ring [Eisenstadt and Gold, 1978], the dose-response curves of epoxide 6 and its parent 


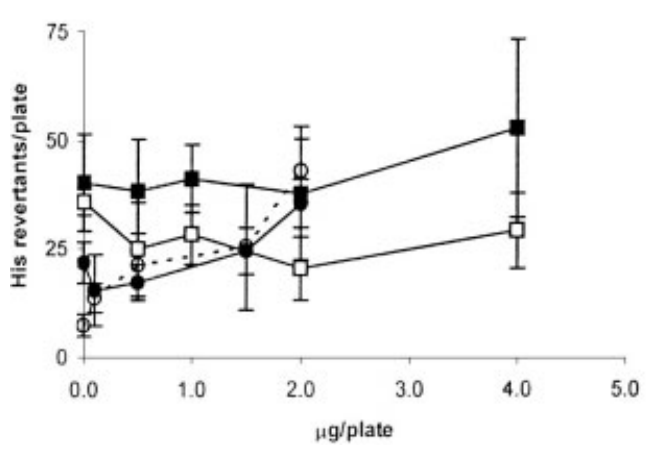

Fig. 6. Comparison of the dose-response mutagenicity of cyclopenta [cd]fluoranthene (1; filled square, $+\mathrm{S} 9 \mathrm{mix}$; open square, $-\mathrm{S} 9 \mathrm{mix})$ and cyclopenta[cd]fluoranthene-3,4-epoxide (6; filled circle, $+\mathrm{S} 9 \mathrm{mix}$; open circle, $-\mathrm{S} 9 \mathrm{mix})$ in S. typhimurium strain TA98 with and without $2 \%(\mathrm{v} / \mathrm{v})$ S9 mix.

compound $\mathbf{1}$ were compared at concentrations up to $2.0 \mu \mathrm{g} /$ plate (Fig. 6). A relatively low concentration test range was used because higher test concentrations of 6 resulted in toxicity (less than confluent background lawn of bacteria on the assay plates; data not shown). 6 was a relatively strong direct-acting mutagen in Salmonella TA98, producing the greatest mutagenic response of the compounds assayed.

\section{DISCUSSION}

In comparison to other CP-PAHs that have been evaluated, 1 was not a particularly strong S9-mediated mutagen (specific mutagenic activity, 0.7 revertants/nmol in TA98; Table IV). For instance, under the same experimental conditions, we found a specific mutagenic activity of 64.6 revertants/nmol for cyclopenta[cd]pyrene [Otero-Lobato et al., 2004b]. Nevertheless, the olefinic bond in the fivemembered ring appears to be required for the mutagenicity of 1 since its corresponding dihydro derivative $\mathbf{4}$ was nonmutagenic. It is noteworthy that epoxide $\mathbf{6}$ is a relatively strong direct-acting mutagen $(-\mathrm{S} 9 \mathrm{mix}$, specific mutagenic activity of 4.1 revertants/nmol). These observations support a scheme whereby epoxidation of the five-membered ring olefinic bond is the main activation pathway. Detoxification of 6 by P450 enzymes is presumably responsible for its reduced mutagenic potency in the presence of $\mathrm{S} 9 \mathrm{mix}$ (specific mutagenic activity of 1.6 vs. 4.1 revertants/nmol without S9; Table IV).

Surprisingly, the ethynyl derivative of 3, i.e., 3-ethynylfluoranthene (2), was mutagenic both with and without S9 mix. In general, E-PAHs inhibit the activity of several $\mathrm{P} 450$ isoenzymes that participate in the metabolic formation of the ultimate mutagenic active forms [Gan et al., 1984; Ortiz de Montellano and Reich, 1986]. The genotoxicity of
2 reported here indicates that the general rule that E-PAHs act as suicide inhibitors is apparently not true for all EPAHs. Other (still untested) E-PAHs are present in combustion exhausts [Lafleur et al., 1988, 1998; Ledesma et al., 1999], and these potentially could also contribute to the total bioactivity of exhausts. In this study, we have demonstrated that a small amount of $\mathbf{2}(\sim 2 \%)$ appears to influence the total mutagenic activity found in the FVT-pyrolysate of $\mathbf{1}$. The necessity of the triple bond for the positive mutagenic response was confirmed by the lack of mutagenic activity for its ethyl-PAH derivative, 5.

Fluoranthene (3) did not exhibit mutagenic activity in this study, both in the presence and in the absence of a metabolic activation mixture. In a previous study, 3 was reported to act as a bacterial mutagen in the conventional and in the tapedplate (for volatile compounds) Salmonella assay [Bos et al., 1988]. Note, however, that this previous study used a considerably higher concentration of microsomal protein in the activation mixture (10\% S9 mix) than was used in our study (2\% S9 mix). For other unsubstituted PAHs, such as phenanthrene, variations in the exogenous metabolic activation mixture were found to affect the mutagenic response greatly [Oesch et al., 1980]. Compound $\mathbf{3}$ also exhibited mutagenic activity in a forward mutation assay using S. typhimurium strain TM677 [Lafleur et al., 1990]. The ultimate mutagenic metabolites in this assay were identified as the diol-epoxides [Rastetter et al., 1982; Day et al., 1992]. Thus, the differences in the mutagenic activity for $\mathbf{3}$ in these studies may be due to different concentrations of protein in the S9 mix [Bos et al., 1988] and to the use of different bacterial tester strains [Lafleur et al., 1990].

The mutagenic activity of cyclopenta[cd]fluoranthene (1), a recently identified constituent of combustion exhausts, was evaluated and shown to possess S9-dependent mutagenicity. It is, however, not as mutagenic as other bioactive mono-CP-PAHs. Its precursor during FVT and presumably combustion, namely, 3-ethynylfluoranthene (2), and the parent compound fluoranthene (3) were also assayed for mutagenicity. Whereas 3 was nonmutagenic under our test conditions, unexpectedly, the E-PAH 2 was mutagenic, both with and without S9 activation. The mutagenicity of $\mathbf{2}$ suggests that other E-PAHs may contribute to the burden of genotoxicity associated with combustion exhausts. More importantly, the generalization that E-PAHs act as inhibitors of some isoenzymes present in the cytochromes $\mathrm{P} 450$ (S9 mix) does not appear to be entirely correct. The partially hydrogenated derivative at the cyclopenta moiety, namely, 3,4-dihydrocyclopenta[cd]fluoranthene (4), was nonmutagenic, indicating the importance of the double bond at the five-membered ring for the mutagenic response. Finally, the direct-acting mutagenicity of cyclopenta[cd]fluoranthene3,4-epoxide (6) was consistent with it being the ultimate mutagenic form of CP-PAH 1. 


\section{ACKNOWLEDGMENTS}

Financial support from the Gobierno Vasco, Beca para Formación de Investigadores (to M.J.O.-L.), and technical support from Dr. A.Y. Simarro and S.M. Nijmeijer (Veterinary Pharmacology, Pharmacy and Toxicology, Utrecht University, The Netherlands) are gratefully acknowledged.

\section{REFERENCES}

Adam W, Bialas J, Hadjiarapoglou L. 1991. A convenient preparation of acetone solutions of dimethyldioxirane. Chem Ber 124:23772378.

Ames BN, McCann J, Yamasaki E. 1975. Methods for detecting carcinogens and mutagens with the Salmonella/mammalian-microsome mutagenicity test. Mutat Res 31:347-364.

Bauschlicher CW Jr, Ricca A. 2000. Mechanism for PAH growth. Chem Phys Lett 326:283-287.

Bockhorn H, Fetting F, Wenz HW. 1983. Investigation of the formation of high molecular hydrocarbons and soot in premixed hydrocarbonoxygen flames. Ber Bunsenges Phys Chem 87:1067-1073.

Bos RP, Theuws JLG, Jongeneelen FJ, Hendreson PT. 1988. Mutagenicity of bi-, tri- and tetra-cyclic aromatic hydrocarbons in the "tapedplate assay" and in the conventional Salmonella mutagenicity assay. Mutat Res 204:203-206.

Busby WF Jr, Smith H, Plummer EF, Lafleur AL, Mulder PPY, Boere BB, Cornelisse J, Lugtenburg J. 1997. Mutagenicity of cyclopenta-fused polynuclear aromatic hydrocarbons and a non-polar fraction from a fuel combustion sample in a Salmonella forward mutation assay without exogenous metabolic activation. Mutat Res 391:117-125.

Cariello NF, Piegorsh WW. 1996. The Ames test: the two-fold rule revisited. Mutat Res 133:23-31.

Cavalieri E, Munhall A, Rogan E, Salmasi S, Patil K. 1983. Syncarcinogenic effect of the environmental pollutants cyclopenteno [cd]pyrene and benzo[a]pyrene in mouse skin. Carcinogenesis 4:393-397.

Claxton L, Allen J, Auletta A, Mortelmans K, Nestmann E, Zeiger E. 1987. Guide for the Salmonella typhimurium/mammalian microsome tests for bacterial mutagenicity. Mutat Res 189:83-91.

Day BW, Sahali Y, Hutchins DA, Wildschutte M, Pastorelli R, Nguyen TT, Naylor S, Skipper PL, Wishnok JS, Tannenbaum SR. 1992. Fluoranthene metabolism: human and rat liver microsomes display different stereoselective formation of the trans-2,3-dihydrodiol. Chem Res Toxicol 5:779-786.

Eisenstadt E, Gold A. 1978. Cyclopenta[cd]pyrene: a highly mutagenic PAH. Proc Natl Acad Sci USA 75:1667-1669.

Environmental Protection Agency. 1997. Title 40, part 60, subparts d, da, db, dc. Washington, DC: Environmental Protection Agency.

Gan L-SL, Acebo AL, Alworth WL. 1984. 1-ethynylpyrene, a suicide inhibitor of cytochrome $\mathrm{P} 450$ dependent benzo[a]pyrene hydroxylase activity in liver microsomes. Biochemistry 23:3827-3836.

Gold A, Eisenstadt E. 1980. Metabolic activation of cyclopenta[cd]pyrene to 3,4-epoxycyclopenta[cd]pyrene by rat liver microsomes. Cancer Res 40:3940-3944.

Gold A, Nesnow S, Moore M, Garland H, Curtis G, Howard B, Graham D, Eisenstadt E. 1980. Mutagenesis and morphological transformation of mammalian cells by a non-bay-region polycyclic cyclopenta [cd]pyrene and its 3,4-oxide. Cancer Res 40:4482-4484.

Hall M, Parker DK, Grover PL, Lu J-YL, Hopkins NE, Alworth WL. 1990. Effects of 1-ethynylpyrene and related inhibitors of P450 isozymes upon benzo[a]pyrene metabolism by liver microsomes. Chem Biol Interact 76:181-192.

Jacob J. 1996. The significance of PAH as environmental carcinogens. Pure Appl Chem 68:301-308.
Jenneskens LW, Sarobe M, Zwikker JW. 1996. Thermal generation and (inter)conversion of (multi)cyclopenta-fused PAH. Pure Appl Chem 68:219-224.

Jenneskens LW, Sarobe M. 1999. Prevalent CP-PAH combustion effluents: build-up and conversion under high temperature conditions in the gas phase. Polycycl Aromat Comp 14-15:169-178.

Jenneskens LW, Vlietstra EJ, Sarobe M, Ponzano SNR. 1999. High temperature chemistry of (non)-alternant PAH: the flash vacuum thermolysis approach-newsletter 10. Richmond, VA: International Society of Polycyclic Aromatic Compounds (ISPAC) Inc.

Kim BS, Margolin BH. 1999. Statistical methods for the Ames Salmonella assay: a review. Mutat Res 436:113-122.

Koper C, Sarobe M, Jenneskens LW. 2004. Redox properties of nonalternant CP-PAH: the effect of peripheral pentagon annelation. Phys Chem Chem Phys 6:319-327.

Lafleur AL, Gagel JJ, Longwell JP, Monchamp PA. 1988. Identification of aromatic alkynes and acyclic polyunsaturated hydrocarbons in the output of a jet-stirred combustor. Energy Fuels 2:709-716.

Lafleur AL, Longwell JP, Shirname-More L, Monchamp PA, Peters WA, Plummer EF. 1990. Chemical characterization and bacterial mutagenicity testing of ethylene combustion products from a jet-stirred/ plug-flow reactor. Energy Fuels 4:307-319.

Lafleur AL, Longwell JP, Marr JA, Monchamp PA, Plummer EF, Thilly WG, Mulder PPY, Boere BB, Cornelisse J, Lugtenburg J. 1993. Bacterial and human cell mutagenicity study of some $\mathrm{C}_{18} \mathrm{H}_{10}$ cyclopenta-fused PAH associated with fossil fuels combustion. Environ Health Perspect 101:146-153.

Lafleur AL, Howard JB, Taghizadeh K, Plummer EF, Scott LT, Necula A, Swallow KC. 1996. Identification of $\mathrm{C}_{20} \mathrm{H}_{10}$ dicyclopentapyrenes in flames: correlation with corannulene and fullerene formation. $\mathrm{J}$ Phys Chem 100:17421-17428.

Lafleur AL, Howard JB, Plummer EF, Taghizadeh K, Necula A, Scott LT, Swallow KC. 1998. Identification of some novel cyclopentafused PAH in ethylene flames. Polycycl Aromat Comp 12:223237.

Ledesma EB, Kalish MA, Wornat MJ, Nelson PF, Mackie JC. 1999. Observation of cyclopenta-fused and ethynyl-substituted PAH during the fuel-rich combustion of primary tar from a bituminous coal. Energy Fuels 13:1167-1172.

Lowry OH, Rosebrough NJ, Farr AL, Randall RJ. 1951. Protein measurement with the folin phenol reagent. J Biol Chem 193:265-275.

Maron DM, Ames BN. 1983. Revised methods for the Salmonella mutagenicity test. Mutat Res 113:173-215.

Mastral AM, Callén MS, García T. 2000. Toxic organic emissions from coal combustion. Fuel Process Technol 67:1-10.

Matijasevic Z, Zeiger E. 1985. Mutagenicity of pyrene in Salmonella. Mutat Res 142:149-152.

Mortelmans K, Zeiger E. 2000. The Ames Salmonella/microsome mutagenicity assay. Mutat Res 455:29-60.

Murray RW, Singh M. 1997. Synthesis of epoxides using dimethyldioxirane: trans-stilbene oxide. Org Synt 74:91-100.

Necula A, Scott LT. 2000. Trapping aryl radicals with acetylene: evidence for $\mathrm{C}_{2}$-accretion as mechanism for PAH growth. J Am Chem Soc 122:1548-1549.

Oesch F, Bucker M, Glatt HR. 1980. Activation of phenanthrene to mutagenic metabolites and evidence for at least two different activation pathways. Mutat Res 81:1-10.

Ortiz de Montellano PR, Reich NO. 1986. Inhibition of cytochrome P-450 enzymes. In: Ortiz de Montellano PR, editor. Cytochrome p-450: structure, mechanism, and biochemistry. New York: Plenum Press. p 273-314.

Otero-Lobato MJ, Jenneskens LW, Seinen W. 2004a. Bacterial mutagenicity of dicyclopenta-fused pyrene congeners in FVT-pyrolysates: partial combustion exhaust mimics. Polycycl Aromat Comp (in press). 
Otero-Lobato MJ, Jenneskens LW, Seinen W. 2004b. Bacterial mutagenicity of the three isomeric dicyclopenta-fused pyrenes: the effects of dicyclopenta topology. Mutat Res 559:105-119.

Rastetter WH, Nachbar RB Jr, Russo-Rodríguez S, Wattley RV, Thilly WG, Andon M, Jorgensen WL, Ibrahim M. 1982. Fluoranthene: synthesis and mutagenicity of four diol epoxides. J Org Chem 47:4873-4878.

Sarobe M, Flink S, Jenneskens LW, van Poecke BLA, Zwikker JW. 1995a. Cyclopent[fg]acepyrylene, cyclopent[jk]acepyrylene and cyclopent[mn]acepyrylene: novel $\mathrm{C}_{20} \mathrm{H}_{10}$ cyclopenta-fused $\mathrm{PAH}$. J Chem Soc Chem Commun 2415-2416.

Sarobe M, Snoeijer JD, Jenneskens LW, Slagt MQ, Zwikker JW. 1995b. Cyclopenta[cd]fluoranthene: acefluoranthylene. Tetrahedron Lett 36:8489-8492

Sarobe M. 1998. Polycyclic aromatic hydrocarbons under high temperature conditions: consequences for carbon build up during combustion and fullerene formation processes. PhD thesis. Utrecht: Utrecht University.

Sarobe M, Kwint HC, Fleer T, Havenith RWA, Jenneskens LW, Vlietstra EJ, van Lenthe JH, Wessseling JW. 1999. Flash vacuum thermolysis of acenaphtho[1,2-a]acenaphthylene, fluoranthene, benzo[k]- and benzo[j]fluoranthene: homolytic scission of carbon-carbon single bonds of internally fused cyclopenta moieties at $\mathrm{T}>1000{ }^{\circ} \mathrm{C}$. Eur J Org Chem 1191-1200.

Wang H, Frenklach M. 1997. A detailed kinetic modeling study of aromatics formation in laminar premixed acetylene and ethylene flames. Combust Flame 110:173-221.

Wiersum UE, Jenneskens LW. 1997. The formation of polyaromatic hydrocarbons, fullerenes and soot in combustion: pyrolytic mechanisms and the industrial and environmental connection. In: Vallée $\mathrm{Y}$, editor. Gas phase reactions in organic synthesis. New York: Gordon and Breach Science Publishers. p 143-194.

Wood AW, Levin W, Chang RL, Huang M, Ryan D, Thomas PE, Lehr R, Kumar S, Koreeda M, Akagi H, et al. 1980. Mutagenicity and tumor-initiating activity cyclopenta[cd]pyrene and structurally related compounds. Cancer Res 40:642-649.

Wortelboer HM, de Kruif CA, van Iersel AAJ, Falke HE, Noordhoek J, Blaauboer BJ. 1990. The isoenzyme pattern of cytochrome P450 in rat hepatocytes in primary culture, comparing different enzyme activities in microsomal incubations and intact monolayers. Biochem Pharm 40:2525-2534. 